ISSN 1392-3196 / e-ISSN 2335-8947

Zemdirbyste-Agriculture, vol. 107, No. 1 (2020), p. 11-16

DOI 10.13080/z-a.2020.107.002

\title{
The content of mineral nitrogen in Histosols and its relationship with soil organic matter
}

\author{
Gediminas STAUGAITIS, Andrius ŠARKA \\ Lithuanian Research Centre for Agriculture and Forestry, Agrochemical Research Laboratory \\ Savanorių 287, Kaunas, Lithuania \\ E-mail: staugaitis@agrolab.lt
}

\begin{abstract}
The aim of the research was to investigate the content of mineral nitrogen $\left(\mathrm{N}_{\min }\right)$ at the 0-30,30-60 and 60-90 cm layers of Histosols and their relationship with soil organic matter (SOM). The experiment was conducted in natural or cultivated perennial meadows of Lithuania in 2016-2018. Every year in November, 21 sites were installed and $\mathrm{N}_{\min }$ was analysed. The studies showed that the content of $\mathrm{N}_{\min }$ in Histosols were significantly higher compared to those in mineral soils, and they widely ranged in the air-dried soil samples at different depths as follows: 37.5 to $128.2 \mathrm{mg} \mathrm{kg}^{-1}$ at $0-30 \mathrm{~cm}, 22.9$ to $143.4 \mathrm{mg} \mathrm{kg}^{-1}$ at $30-60 \mathrm{~cm}$ and 5.2 to $85.3 \mathrm{mg} \mathrm{kg}^{-1}$ at $60-90 \mathrm{~cm}$. $\mathrm{N}_{\min }$ content at the 0-30 and 30-60 cm layers were lower in Bathiterric Histosol and Bathifibric-Fibric Histosol compared to those in Pachiterric Histosol and Pachiterri-Fibric Histosol. In addition, the content of $\mathrm{N}_{\min }$ in Histosols depended on the peat layer thickness. At the 60-90 cm layer of Pachiterric Histosol and Pachiterri-Fibric Histosol, mineral soil was already present in many of the profiles, and SOM was lower, therefore, $\mathrm{N}_{\min }$ content was lower as well. The content of $\mathrm{N}_{\min }\left(\mathrm{y}, \mathrm{mg} \mathrm{kg}^{-1}\right)$ in Histosols was strongly dependent on the content of SOM in the soil (x, \%). This dependence at the $0-30 \mathrm{~cm}$ layer is expressed by the equations: $\mathrm{y}=-0.02 \mathrm{x}^{2}+2.72 \mathrm{x}-6.41\left(r=0.87^{*}\right)$, at $30-60 \mathrm{~cm}$ layer $-\mathrm{y}=-0.01 \mathrm{x}^{2}+2.2 \mathrm{x}+0.31\left(r=0.87^{*}\right)$, and at $60-90 \mathrm{~cm}$ layer $-\mathrm{y}=0.78 \mathrm{x}+7.82(r=0.92 * *)$. At the $0-30 \mathrm{~cm}$ Histosols layer, the average ratio of carbon-to-nitrogen $(\mathrm{C}: \mathrm{N})$ was 18 , and a very strong correlation was obtained between the ratio of C:N and $\mathrm{N}_{\min }$ content. At the 30-60 $\mathrm{cm}$ layer the ratio of C:N averaged 27, resulting in a weak correlation, leading to a higher impact of SOM concentration on $\mathrm{N}_{\min }$ content. At the $60-90 \mathrm{~cm}$ layer, in the shallow peat soils mineral horizon dominated, resulting in a high variation of the ratio of C:N from 4 to 34 and there was no correlation between the ratio of $\mathrm{C}: \mathrm{N}$ and $\mathrm{N}_{\text {min }}$ content.
\end{abstract}

Key words: Histosols, mineral nitrogen, soil organic carbon.

\section{Introduction}

The content of mineral nitrogen $\left(\mathrm{N}_{\min }\right)$ in the soil allows us to estimate the stocks of nitrogen readily available to plants, therefore, it is used to calculate the required nitrogen fertiliser rates, estimate available nitrogen leaching and assess how nitrates move down the soil profile, etc. (Robertson, Vitousek, 2009; Shcherbak et al., 2014; Rezanezhad et al., 2016). Considering soil texture, $\mathrm{N}_{\text {min }}$ scales of assessment in mineral soils are developed (Staugaitis et al., 2007; Arbačiauskas et al., 2014). Optimal terms of soil sampling for $\mathrm{N}_{\text {in }}$ analyses are determined in different countries according to climatic conditions, the depths from which samples are taken for different agricultural crops and other methodological requirements (Staugaitis et al., 2014; Zhang et al., 2015; Arbačauskas et al., 2018). Most of these studies are conducted early in spring and autumn, less often in summer, as due to intense mineralisation of plant residues and organic matter in the soil, the content of $\mathrm{N}_{\text {min }}$ significantly increases (Aurangojeb et al., 2017; Friesen, Cattani, 2017; Tripolskaja et al., 2017). This increase mainly occurs in the upper $0-30 \mathrm{~cm}$ soil layer (Deng et al., 2016; Wasiu et al., 2018).
It has been documented that the content of $\mathrm{N}_{\text {min }}$ in the soil depends on the content of soil organic matter (SOM) (Zang et al., 2000; Ruehlmann, Körschens, 2009; Parvage et al., 2015). However, SOM differs in quality and therefore affects the content of $\mathrm{N}_{\min }$ (Sommer et al., 2004; Dawson et al., 2008; Wang et al 2015; Wei et al., 2017). As mineralisation of peaty soil increases, the size of organic particles decreases, thus reducing the pores and increasing dry soil mass per unit volume (Castillo, Writ, 2008; Volungevičius et al., 2015; Rezanezhad et al., 2016). This results in a change of soil bulk density, which affects chemical, biological and hydrological properties of peaty soil and thus the content of available nitrogen (Johnston et al., 2001; Chambers et al., 2010; Truong, Marschner, 2018). SOM mineralisation in Histosols takes place more intensively in the upper layer, and this process is influenced by many factors, including the degree of peat fragmentation, soil moisture, temperature, plants grown, stocks of plant residues left (Burri et al., 2018; Vasilevich et al., 2018).

$\mathrm{N}_{\text {min }}$ is significantly higher in soils with high SOM, such as Gleysols and especially Histosols

Please use the following format when citing the article:

Staugaitis G., Šarka A. 2020. The content of mineral nitrogen in Histosols and its relationship with soil organic matter. ZemdirbysteAgriculture, 107 (1): 11-16. DOI 10.13080/z-a.2020.107.002 
(Vasilevich et al., 2018). Due to this reason, $\mathrm{N}_{\mathrm{m}}$ assessment scales used for mineral soils are not suitable for these soils (Steffens et al., 2014; Norberg et al., 2016), and there is not enough research to develop them. There is also a lack of research on $\mathrm{N}_{\min }$ variations in Histosols with different thickness of peat layers. Therefore, the aim of this research was to investigate the content of $\mathrm{N}_{\text {min }}$ in Histosols, and to assess how the content of $\mathrm{N}_{\min }$ varies at different depths and depends on the content of SOM.

\section{Materials and methods}

The experiment was conducted in Varéna, Ukmerge and Raseiniai municipalities in southern and central Lithuania in 2016-2018. Twenty one sites with an area of $100 \mathrm{~m}^{2}(10 \times 10 \mathrm{~m})$ were installed in natural or cultivated perennial meadows, where grass was cut or grazed. The selected sites were marked with a GPS device and soil samples were taken from the same locations for analysis. At each site, a composite soil sample was taken from 5-6 spots using a soil probe. Soil samples were taken in the autumn (20-30 of November) from the $0-30,30-60$ and $60-90 \mathrm{~cm}$ soil layers. The soil code (according to WRB, 2014), coordinates of the experimental site, soil profile and its bulk density are presented in Table 1. Histosol horizon by type is divided into: low peat soils $0-30 \mathrm{~cm}\left(\mathrm{O}-\mathrm{Hs}-\mathrm{H}_{3}\right.$ or $\left.\mathrm{Hs}-\mathrm{H}_{3}\right), 30-60$ $\mathrm{cm}\left(\mathrm{H}_{2}\right)$ and $60-90 \mathrm{~cm}(2 \mathrm{Ckr}-2 \mathrm{Cr}$ or $2 \mathrm{Cr})$, and deep peat soils $0-30 \mathrm{~cm}\left(\mathrm{O}-\mathrm{Hs}_{-} \mathrm{H}_{3}\right.$ or $\left.\mathrm{Hs}-\mathrm{H}_{3}\right), 30-60 \mathrm{~cm}\left(\mathrm{H}_{2}\right)$ and 60-90 $\mathrm{cm}\left(\mathrm{H}_{2}\right)$.
Soil samples collected for mineral nitrogen $\left(\mathrm{N}_{\text {min }}\right)$ analyses were stored in thermal boxes at $0-+3^{\circ} \mathrm{C}$ during transportation. The moisture of soil samples was determined according to gravimetric method (ISO 11465:1993. Soil quality - Determination of dry matter and water content on a mass basis) by drying the soil at $105^{\circ} \mathrm{C}$ to a constant weight. Mineral nitrogen (N$\mathrm{NO}_{3}$ and $\mathrm{N}-\mathrm{NH}_{4}$ ) in dried soil samples was determined after extraction with $1 \mathrm{M} \mathrm{KCl}$ (1:5 ratio) according to ISO 14256-2005 (Determination of nitrate, nitrite and ammonium in field-moist soils by extraction with potassium chloride solution). Nitrate and ammonium nitrogen content was determined using the FIAstar 5000 Analyser (Foss Analytical A/S, Denmark). Soil organic matter (SOM) was measured by elementary analysis according to ISO 10694:1995 (Determination of organic and total carbon after dry combustion), and the bulk density - according to EN 13040:2008 (Sample preparation for chemical and physical tests, determination of dry matter concentration). Undisturbed core samples for determination of soil bulk density and total porosity were collected using stainless steel rings (100 $\mathrm{cm}^{3}$ volumes) in four replications. Bulk density and total porosity were calculated from undisturbed soil samples. Soil organic carbon (SOC) content was determined by the Tyurin method modified by Nikitin (1999) with a spectrophotometric measure procedure at the wavelength of $590 \mathrm{~nm}$ and glucose as a standard. Soil total nitrogen $(\mathrm{N})$ was determined by the Kjeldhal method with a photometric measure procedure at the wavelength of $655 \mathrm{~nm}$.

Table 1. Coordinates, soil profiles and bulk density of the research sites

\begin{tabular}{|c|c|c|c|c|c|c|}
\hline \multirow{2}{*}{ Site No. } & \multirow{2}{*}{$\begin{array}{c}\text { Soil code } \\
\text { according to FAO }\end{array}$} & \multirow{2}{*}{ Coordinates } & \multirow{2}{*}{$\begin{array}{c}\text { Soil } \\
\text { profile }\end{array}$} & \multicolumn{3}{|c|}{ Bulk density $\mathrm{Mg} \mathrm{m}^{-3}$} \\
\hline & & & & $0-30 \mathrm{~cm}$ & $30-60 \mathrm{~cm}$ & $60-90 \mathrm{~cm}$ \\
\hline 1. & $A R g-p-w-e u$ & $52^{\circ} 81^{\prime} 88 \mathrm{~N}, 60^{\circ} 10^{\prime} 19 \mathrm{E}$ & Ah-Bg-Cg & $1.35 \pm 0.05$ & $1.4 \pm 0.03$ & $1.5 \pm 0.02$ \\
\hline 2. & $A R g-p-w-e u$ & $37^{\circ} 13^{\prime} 74 \mathrm{~N}, 61^{\circ} 14^{\prime} 42 \mathrm{E}$ & $\mathrm{Ah}-\mathrm{Bg}-\mathrm{Cg}$ & $1.44 \pm 0.03$ & $1.4 \pm 0.05$ & $1.5 \pm 0.03$ \\
\hline 3 . & Glu-ha & $52^{\circ} 87^{\prime} 89 \mathrm{~N}, 61^{\circ} 11^{\prime} 97 \mathrm{E}$ & $\mathrm{Ah}-\mathrm{Bg}-\mathrm{Cg}$ & $1.28 \pm 0.03$ & $1.3 \pm 0.02$ & $1.4 \pm 0.02$ \\
\hline 4. & $H S f-s-p h$ & $41^{\circ} 06^{\prime} 82 \mathrm{~N}, 61^{\circ} 41^{\prime} 22 \mathrm{E}$ & $\mathrm{O}-\mathrm{Hs}-\mathrm{H}_{3}-\mathrm{H}_{2}-\mathrm{Cr}$ & $0.85 \pm 0.07$ & $0.8 \pm 0.07$ & $1.5 \pm 0.07$ \\
\hline 5. & $H S s-p h$ & $52^{\circ} 86^{\prime} 19 \mathrm{~N}, 60^{\circ} 10^{\prime} 51 \mathrm{E}$ & $\mathrm{O}-\mathrm{Hs}-\mathrm{H}_{3}^{3}-\mathrm{H}_{2}^{2}-2 \mathrm{Cr}$ & $0.91 \pm 0.11$ & $1.0 \pm 0.11$ & $1.3 \pm 0.11$ \\
\hline 6. & $H S f-s-d$ & $42^{\circ} 97^{\prime} 80 \mathrm{~N}, 61^{\circ} 41^{\prime} 15 \mathrm{E}$ & $\mathrm{O}-\mathrm{Hs}^{3}-\mathrm{H}_{3}-\mathrm{H}_{2}$ & $0.83 \pm 0.09$ & $0.5 \pm 0.09$ & $0.5 \pm 0.09$ \\
\hline 7. & $H S s-d$ & $37^{\circ} 32^{\prime} 22 \mathrm{~N}, 61^{\circ} 13^{\prime} 30 \mathrm{E}$ & $\mathrm{Hs}-\mathrm{H}_{3}-\mathrm{H}_{2}$ & $0.97 \pm 0.08$ & $0.9 \pm 0.08$ & $0.8 \pm 0.08$ \\
\hline 8. & $H S f-s-p h$ & $41^{\circ} 06^{\prime} 75 \mathrm{~N}, 61^{\circ} 41^{\prime} 18 \mathrm{E}$ & $\mathrm{Hs}-\mathrm{H}_{3}-\mathrm{H}_{2}-2 \mathrm{Ckr}^{2}-2 \mathrm{Cr}$ & $0.92 \pm 0.06$ & $1.1 \pm 0.06$ & $1.5 \pm 0.06$ \\
\hline 9. & $H S s-d$ & $37^{\circ} 25^{\prime} 01 \mathrm{~N}, 61^{\circ} 13^{\prime} 67 \mathrm{E}$ & $\mathrm{Hs}_{2}-\mathrm{H}_{3}-\mathrm{H}_{2}$ & $0.71 \pm 0.09$ & $0.7 \pm 0.09$ & $0.6 \pm 0.09$ \\
\hline 10. & $H S f-s-p h$ & $54^{\circ} 02^{\prime} 59 \mathrm{~N}, 61^{\circ} 26^{\prime} 36 \mathrm{E}$ & $\mathrm{O}-\mathrm{Hs}-\mathrm{H}_{3}-\mathrm{H}_{2}^{2}-2 \mathrm{Cr}$ & $0.94 \pm 0.08$ & $0.8 \pm 0.08$ & $1.3 \pm 0.08$ \\
\hline 11. & $H S s-p h$ & $52^{\circ} 28^{\prime} 49 \mathrm{~N}, 60^{\circ} 11^{\prime} 71 \mathrm{E}$ & $\mathrm{O}-\mathrm{Hs}-\mathrm{H}_{3}^{3}-\mathrm{H}_{2}^{2}-2 \mathrm{Cr}$ & $0.73 \pm 0.07$ & $0.6 \pm 0.07$ & $1.2 \pm 0.07$ \\
\hline 12. & $H S s-d$ & $52^{\circ} 86^{\prime} 37 \mathrm{~N}, 60^{\circ} 10^{\prime} 53 \mathrm{E}$ & $\mathrm{Hs}-\mathrm{H}_{3}-\mathrm{H}_{2}$ & $0.82 \pm 0.07$ & $0.8 \pm 0.07$ & $0.8 \pm 0.07$ \\
\hline 13. & $H S f-s-d$ & $51^{\circ} 29^{\prime} 56 \mathrm{~N}, 60^{\circ} 61^{\prime} 35 \mathrm{E}$ & $\mathrm{Hs}-\mathrm{H}_{3}^{3}-\mathrm{H}_{2}^{2}$ & $0.93 \pm 0.08$ & $0.7 \pm 0.08$ & $0.6 \pm 0.08$ \\
\hline 14. & $H S s-p h$ & $52^{\circ} 86^{\prime} 69 \mathrm{~N}, 61^{\circ} 10^{\prime} 51 \mathrm{E}$ & $\mathrm{Hs}-\mathrm{H}_{3}-\mathrm{H}_{2}-2 \mathrm{Ckr}^{2}-2 \mathrm{Cr}$ & $0.93 \pm 0.11$ & $0.9 \pm 0.11$ & $1.6 \pm 0.11$ \\
\hline 15. & $H S f-s-d$ & $51^{\circ} 29^{\prime} 54 \mathrm{~N}, 60^{\circ} 61^{\prime} 33 \mathrm{E}$ & $\mathrm{Hs}_{2}-\mathrm{H}_{3}-\mathrm{H}_{2}$ & $0.81 \pm 0.12$ & $0.7 \pm 0.12$ & $0.6 \pm 0.12$ \\
\hline 16. & $H S f-s-d$ & $55^{\circ} 41^{\prime} 47 \mathrm{~N}, 60^{\circ} 36^{\prime} 39 \mathrm{E}$ & $\mathrm{O}-\mathrm{Hs}_{2}-\mathrm{H}_{3}-\mathrm{H}_{2}$ & $0.87 \pm 0.07$ & $0.9 \pm 0.09$ & $0.9 \pm 0.07$ \\
\hline 17. & $H S f-s-p h$ & $54^{\circ} 06^{\prime} 54 \mathrm{~N}, 61^{\circ} 26^{\prime} 69 \mathrm{E}$ & $\mathrm{Hs}-\mathrm{H}_{3}-\mathrm{H}_{2}^{3}-2 \mathrm{Cr}$ & $0.81 \pm 0.07$ & $0.8 \pm 0.11$ & $1.4 \pm 0.07$ \\
\hline 18. & $H S s-d$ & $52^{\circ} 82^{\prime} 67 \mathrm{~N}, 61^{\circ} 11^{\prime} 71 \mathrm{E}$ & & $0.76 \pm 0.08$ & $0.6 \pm 0.12$ & $0.7 \pm 0.08$ \\
\hline 19. & $H S s-p h$ & $55^{\circ} 50^{\prime} 95 \mathrm{~N}, 60^{\circ} 32^{\prime} 23 \mathrm{E}$ & $\mathrm{O}-\mathrm{Hs}-\mathrm{H}_{3}-\mathrm{H}_{2}^{2}-2 \mathrm{Cr}$ & $0.91 \pm 0.11$ & $0.8 \pm 0.11$ & $1.2 \pm 0.11$ \\
\hline 20. & $H S s-p h$ & $55^{\circ} 64^{\prime} 69 \mathrm{~N}, 60^{\circ} 33^{\prime} 22 \mathrm{E}$ & $\mathrm{Hs}-\mathrm{H}_{3}-\mathrm{H}_{2}-2 \mathrm{C} \mathrm{kr}-2 \mathrm{Cr}$ & $0.74 \pm 0.07$ & $0.7 \pm 0.12$ & $1.1 \pm 0.14$ \\
\hline 21. & $H S f-S-p h$ & $52^{\circ} 28^{\prime} 49 \mathrm{~N}, 60^{\circ} 11^{\prime} 33 \mathrm{E}$ & $\mathrm{Hs}^{3}-\mathrm{H}_{3}^{2}-\mathrm{H}_{2}-2 \mathrm{Cr}$ & $0.93 \pm 0.12$ & $0.7 \pm 0.09$ & $1.1 \pm 0.13$ \\
\hline
\end{tabular}

ARg-p-w-eu - Eutri-Epihypogleyic Arenosol, Glu-ha - Hapli-Umbric Geysol, HSs-d-Bathiterric Histosol (low moor deep peat soils $\geq 100 \mathrm{~cm}$ ), HSs-ph-Pachiterric Histosol (low moor shallow peat soils 40-100 cm), HSf-s-d-Bathifibric-Fibric Histosol (high moor deep peat soils $\geq 100 \mathrm{~cm}$ ), HSf-s-ph-Pachiterri-Fibric Histosol (high moor shallow peat soils 50-100 cm); A-decomposition organic material is taking place, $\mathrm{h}$ - humic horizon, $\mathrm{Bg}$ - mineral surface horizon, $\mathrm{O}$ - turtle horizon, $\mathrm{Hs}-$ mineralized peat, $\mathrm{H}_{3}-$ severely decomposed peat, $\mathrm{H}_{2}$ - moderately decomposed peat, $\mathrm{Cg}$ - underground rock horizon, $2 \mathrm{Ckr}$ - soil of organic origin, $2 \mathrm{Cr}$ - deposited sediments from which soil formed, parent material; \pm - standard deviation of the mean

Meteorological conditions. Research objects in the territory of Lithuania are located in the south-eastern part of the Baltic Sea, where the climate is maritimecontinental, in winter (December-February) the average daily temperature reaches $-2--3^{\circ} \mathrm{C}$, in summer (JuneAugust) - $16.0-18.5^{\circ} \mathrm{C}$. Monthly precipitation in November-May and September is $38-50 \mathrm{~mm}$, with more abundant - 60-64 $\mathrm{mm}$ precipitation in June, August and October, and the wettest month is July $-79 \mathrm{~mm}$. The climate in the area is favourable for grass cultivation.
During the experimental period until the second half of November, when soil samples were taken for mineral nitrogen analyses, the meteorological conditions for individual years were different (Fig. 1).

The weather conditions in 2016 were close to multiannual ones; however, in August-November precipitation in the research sites was more abundant compared to multiannual averages: in August, 53-83\%, in September - 71-96\%, in October $30-46 \%$ and in November $-43-85 \%$ more. The moisture concentration 


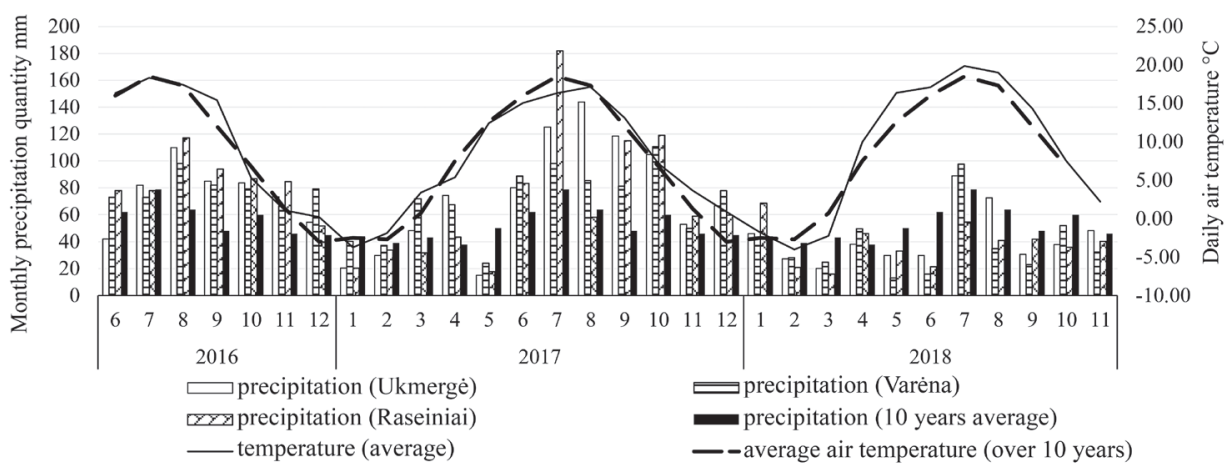

Figure 1. Monthly average daily air temperature and monthly precipitation in 2016-2018

of peat taken for analysis varied between 60-70\% during that year. The year 2017 was extremely rainy. During the June-October period, the amount of precipitation exceeded normal by $25-100 \%$ for individual months, and in November the lower-lying locations with perennial grasses were covered with water. The soil samples taken for the experiment were wet, especially those taken from more than $60 \mathrm{~cm}$ depth. The moisture concentration found in the peat was in the range $80-90 \%$. The year 2018 was dry. The average daily air temperature was $0.7-3.8^{\circ} \mathrm{C}$ higher than the multiannual average during individual months starting from March. In March-May this difference was $+2.5-+3.8^{\circ} \mathrm{C}$. During that year, precipitation was lower compared to normal starting from February, and since June plants felt lack of moisture. In that year, grasses were thinner, and the moisture concentration in peat samples ranged from $50 \%$ to $60 \%$. Its lowest value $(45 \%)$ was recorded in the $0-30 \mathrm{~cm}$ layer.

The experimental data were evaluated and presented as an arithmetic mean and the mean standard deviation was calculated. The equation $y=a^{2}+b x+c$ was used to calculate the relationship between $\mathrm{N}_{\min }$ and SOM. The value of the minimum significant difference $(R)$ is calculated and the marking $* *$ refers to the statistical significance for $R_{01}$ level and * - statistical significance for $R_{05}$ level. Three-year $\mathrm{N}_{\text {min }}$ content and SOM concentration data were analysed by a combined analysis of variance (ANOVA) as described by Petersen (1994).

\section{Results and discussion}

Having investigated eighteen Histosols, the content of $\mathrm{N}_{\text {in }}$ at various depths was high and varied within a wide range: $37.5-113.0 \mathrm{mg} \mathrm{kg}^{-1}$ at the $0-30 \mathrm{~cm}$ layer, $48.3-143.4 \mathrm{mg} \mathrm{kg}^{-1}$ at $30-60 \mathrm{~cm}$, and 6.3 to $64.9 \mathrm{mg} \mathrm{kg}^{-1}$ at $60-90 \mathrm{~cm}$ in 2016. In 2017, these variations were 64.7$128.2 \mathrm{mg} \mathrm{kg}^{-1}, 22.9-109.3 \mathrm{mg} \mathrm{kg}^{-1}$ and $9.4-83.3 \mathrm{mg} \mathrm{kg}^{-1}$, respectively; in 2018 they were $43.4-99.7 \mathrm{mg} \mathrm{kg}^{-1}, 63.6-$ $113.0 \mathrm{mg} \mathrm{kg}^{-1}$ and $5.2-85.3 \mathrm{mg} \mathrm{kg}^{-1}$. Thus, the highest content of $\mathrm{N}_{\text {min }}$ wat the $0-30$ and $30-60 \mathrm{~cm}$ layers, and at the $60-90 \mathrm{~cm}$ layer it was lower in most Pachiterric Histosol and Pachiterri-Fibric Histosol, where peat ended at the $60-80 \mathrm{~cm}$ depth and the mineral soil layer started.

For comparison, in mineral soils - EutriEpihypogleyic Arenosol - these variations for all the years of the experiment fell within the range of 1.5 $3.6 \mathrm{mg} \mathrm{kg}^{-1}$ at the $0-30 \mathrm{~cm}$ layer, $1.5-3.2 \mathrm{mg} \mathrm{kg}^{-1}$ at 30 $60 \mathrm{~cm}$ layer and $1.4-2.6 \mathrm{mg} \mathrm{kg}^{-1}$ at the $60-90 \mathrm{~cm}$ layer. $\mathrm{N}_{\text {min }}$ content in another investigated Hapli-Umbric Geysol was significantly higher than that in Eutri-Epihypogleyic Arenosol; however, it did not reach the one found in peat and ranged from 8.5 to $20.3 \mathrm{mg} \mathrm{kg}^{-1}$ at the $0-30 \mathrm{~cm}$ layer, $3.3-23.3 \mathrm{mg} \mathrm{kg}^{-1}$ at the $30-60 \mathrm{~cm}$ layer and was particularly low at the $60-90 \mathrm{~cm}$ layer $-0.8-1.2 \mathrm{mg} \mathrm{kg}^{-1}$, respectively. This influenced higher concentration of SOM at the $0-30 \mathrm{~cm}$ and $30-60 \mathrm{~cm}$ layers in this soil $-2.91 \%$ and $0.87 \%$, respectively, and very low content at the 60 $90 \mathrm{~cm}$ layer - merely $0.18 \%$.

By grouping the content of $\mathrm{N}_{\min }$ obtained from the soil profile according to peat types, it was found that at the $0-30$ and $30-60 \mathrm{~cm}$ layers it was the lowest in Bathiterric Histosol (HSs-d) and Bathifibric-Fibric Histosol (HSf-s-d) (Table 2).

Based on three-year data average they were $77.6 \pm 11.3$ and $74.0 \pm 7.61 \mathrm{mg} \mathrm{kg}^{-1}$ at the $0-30 \mathrm{~cm}$ layer and $66.7 \pm 9.18$ and $74.8 \pm 7.53 \mathrm{mg} \mathrm{kg}^{-1}$ at the 30-60 cm layer, respectively. Meanwhile, $\mathrm{N}_{\min }$ content in Pachiterric Histosol (HSs-ph) and Pachiterri-Fibric Histosol (HSf-s-ph) was higher: $80.4 \pm 8.40$ and $90.1 \pm$ $10.7 \mathrm{mg} \mathrm{kg}^{-1}$ at the $0-30 \mathrm{~cm}$ layer and $85.8 \pm 7.37$ and $84.6 \pm 10.1 \mathrm{mg} \mathrm{kg}^{-1}$ at the $30-60 \mathrm{~cm}$ layer, respectively. $\mathrm{N}_{\text {min }}$ content at the $60-90 \mathrm{~cm}$ layer in these soils was lower $-13.5 \pm 4.21$ and $18.1 \pm 4.90 \mathrm{mg} \mathrm{kg}^{-1}$, respectively, whereas in Bathiterric Histosol (HSs-d) and BathifibricFibric Histosol $(H S f-s-d)$ it was $59.0 \pm 8.14$ and $60.8 \pm$ $9.15 \mathrm{mg} \mathrm{kg}^{-1}$, respectively.

The content of $\mathrm{N}$. depended both on the soil type and the content of SOM. The dependence of $\mathrm{N}_{\text {in }}$ content at the $0-30,30-60$ and $60-90 \mathrm{~cm}$ soil layers on the content of SOM is presented in Figure 2. SOM and $\mathrm{N}_{\min }$ contents at the $0-30$ and $30-60 \mathrm{~cm}$ layers were similar; therefore, the interdependence of these indicators at these depths varied marginally. The highest $\mathrm{N}$ content slightly above $80 \mathrm{mg} \mathrm{kg}^{-1}$ was found when SOM was higher than 60\%. Meanwhile, at the $60-90 \mathrm{~cm}$ layer in $H S s$-ph and HSf-s-ph, the mineral soil layer was located just below the peat layer, which affected the decrease in SOM and $\mathrm{N}_{\text {min }}$. Therefore, after analysing all Histosols with $60 \% \mathrm{SOM}$ at this depth it can be stated that the average $\mathrm{N}_{\min }$ value was $52.7 \mathrm{mg} \mathrm{kg}^{-1}$.

A significant indicator for qualitative assessment of soils with organic matter is the ratio of carbon-tonitrogen (C:N) (Grandy et al., 2008). If in our experiment in mineral soils - Eutri-Epihypogleyic Arenosol and Hapli-Umbric Geysol - at 0-30 cm the obtained C:N was respectively 11 and 13 , and at $30-60 \mathrm{~cm} 8$ and 20 it was significantly higher in Histosols (Table 3), which slows down the mineralization of the peat soils (Tian et al., 2010). At the 30-60 cm layer the average of the $\mathrm{C}: \mathrm{N}$ in HSs-ph, HSf-S-ph, HSf-S-D and HSs-D was 16 20 and at the $30-60 \mathrm{~cm}$, with high SOM content, the ratio was 27-29. Meanwhile, at the 60-90 cm layer HSs-ph and $H S f-s$-ph already had a mineral soil in many of the profiles tested, resulting in a significant difference of the $\mathrm{C}: \mathrm{N}$ with an average of only 4-5, when the HSf-S-D and $H S s-D$ averaged $26-34$.

The relationship between the $\mathrm{C}: \mathrm{N}$ and $\mathrm{N}_{\mathrm{m}}$ content in Histosols depended on the depth analysed. At the $0-30 \mathrm{~cm}$ layer, there was mineralized peat, a very strong correlation $(r=0.99 * *)$ was obtained, and the 
Table 2. The content of mineral nitrogen $\left(\mathrm{N}_{\min }\right)$ and soil organic matter (SOM) in the soils studied

\begin{tabular}{|c|c|c|c|c|c|c|c|}
\hline \multirow{2}{*}{$\begin{array}{l}\text { Site } \\
\text { No. }\end{array}$} & \multirow{2}{*}{$\begin{array}{l}\text { Soil code } \\
\text { according to } \\
\text { FAO }\end{array}$} & \multicolumn{3}{|c|}{$\mathrm{N}_{\min } \mathrm{mg} \mathrm{kg}^{-1}$} & \multicolumn{3}{|c|}{ SOM \% } \\
\hline & & $0-30 \mathrm{~cm}$ & $30-60 \mathrm{~cm}$ & $60-90 \mathrm{~cm}$ & $0-30 \mathrm{~cm}$ & $30-60 \mathrm{~cm}$ & $60-90 \mathrm{~cm}$ \\
\hline 1 & $A R g-p-w-e u$ & $2.9 \pm 1.09$ & $1.8 \pm 0.58$ & $1.2 \pm 0.82$ & $1.9 \pm 0.11$ & $0.83 \pm 0.08$ & $0.11 \pm 0.05$ \\
\hline 2 & ARg-p-w-eu & $2.4 \pm 1.32$ & $2.5 \pm 0.92$ & $0.8 \pm 0.31$ & $3.9 \pm 0.21$ & $0.92 \pm 0.12$ & $0.26 \pm 0.09$ \\
\hline 3 & Glu & $44.9 \pm 2.84$ & $23.3 \pm 4.24$ & $1.6 \pm 0.82$ & $12.7 \pm 0.31$ & $2.77 \pm 0.86$ & $1.20 \pm 0.68$ \\
\hline 4 & $H S f-s-p h$ & $63.2 \pm 6.41$ & $93.4 \pm 8.77$ & $11.7 \pm 4.10$ & $32.0 \pm 1.62$ & $43.6 \pm 1.64$ & $1.04 \pm 0.11$ \\
\hline 5 & $H S s-p h$ & $83.1 \pm 11.2$ & $115 \pm 9.07$ & $10.5 \pm 1.24$ & $54.1 \pm 1.87$ & $64.4 \pm 0.75$ & $2.83 \pm 0.38$ \\
\hline 6 & $H S s-d$ & $61.2 \pm 7.22$ & $53.5 \pm 10.4$ & $37.2 \pm 4.42$ & $37.5 \pm 0.40$ & $32.6 \pm 2.72$ & $53.6 \pm 0.70$ \\
\hline 7 & $H S f-s-d$ & $63.9 \pm 8.82$ & $93.5 \pm 8.20$ & $54.6 \pm 8.42$ & $78.1 \pm 1.11$ & $81.5 \pm 0.76$ & $76.0 \pm 1.62$ \\
\hline 8 & $H S f-s-p h$ & $80.6 \pm 19.9$ & $86.7 \pm 8.81$ & $24.3 \pm 2.10$ & $51.5 \pm 1.25$ & $50.5 \pm 0.40$ & $7.52 \pm 0.08$ \\
\hline 9 & $H S f-s-d$ & $62.9 \pm 5.66$ & $90.6 \pm 6.62$ & $63.8 \pm 8.41$ & $41.6 \pm 0.68$ & $74.6 \pm 2.12$ & $70.0 \pm 0.76$ \\
\hline 10 & $H S f-s-p h$ & $109 \pm 11.2$ & $80.9 \pm 9.91$ & $7.47 \pm 2.02$ & $58.8 \pm 1.26$ & $56.0 \pm 1.97$ & $4.24 \pm 0.15$ \\
\hline 11 & $H S s-p h$ & $78.8 \pm 8.82$ & $92.3 \pm 12.2$ & $11.7 \pm 2.31$ & $67.3 \pm 0.74$ & $66.9 \pm 0.75$ & $1.50 \pm 0.07$ \\
\hline 12 & $H S f-S-d$ & $80.4 \pm 5.42$ & $91.5 \pm 7.61$ & $68.5 \pm 9.44$ & $69.5 \pm 0.89$ & $81.4 \pm 1.08$ & $73.1 \pm 0.82$ \\
\hline 13 & $H S s-d$ & $75.9 \pm 10.4$ & $66.0 \pm 9.79$ & $55.3 \pm 7.72$ & $44.0 \pm 0.80$ & $68.1 \pm 0.80$ & $62.2 \pm 1.60$ \\
\hline 14 & $H S s-p h$ & $80.3 \pm 12.2$ & $17.1 \pm 4.48$ & $17.1 \pm 5.16$ & $67.1 \pm 2.07$ & $41.8 \pm 1.29$ & $3.43 \pm 0.12$ \\
\hline 15 & $H S s-d$ & $86.2 \pm 9.91$ & $74.6 \pm 9.48$ & $74.6 \pm 6.62$ & $65.2 \pm 1.78$ & $64.6 \pm 1.59$ & $83.5 \pm 1.47$ \\
\hline 16 & $H S s-d$ & $87.2 \pm 5.92$ & $69.2 \pm 6.47$ & $69.1 \pm 7.73$ & $67.6 \pm 0.40$ & $65.9 \pm 0.71$ & $87.5 \pm 0.50$ \\
\hline 17 & $H S f-s-p h$ & $97.4 \pm 12.2$ & $21.3 \pm 3.42$ & $21.3 \pm 4.40$ & $64.5 \pm 1.53$ & $86.6 \pm 1.42$ & $31.2 \pm 0.78$ \\
\hline 18 & $H S f-s-d$ & $91.2 \pm 9.41$ & $56.1 \pm 6.16$ & $56.1 \pm 8.61$ & $72.8 \pm 0.51$ & $72.1 \pm 1.71$ & $52.4 \pm 1.23$ \\
\hline 19 & $H S s-p h$ & $74.4 \pm 14.2$ & $71.9 \pm 4.97$ & $25.4 \pm 10.4$ & $68.9 \pm 1.32$ & $64.6 \pm 1.15$ & $4.03 \pm 0.21$ \\
\hline 20 & $H S s-p h$ & $85.6 \pm 8.82$ & $74.1 \pm 7.13$ & $66.3 \pm 2.53$ & $54.6 \pm 0.58$ & $63.3 \pm 1.12$ & $2.11 \pm 0.33$ \\
\hline 21 & $H S f-s-p h$ & $99.7 \pm 11.8$ & $72.1 \pm 5.61$ & $8.71 \pm 9.15$ & $77.5 \pm 0.61$ & $47.3 \pm 0.70$ & $22.1 \pm 0.65$ \\
\hline \multicolumn{8}{|c|}{ Average } \\
\hline 1,2 & $A R g-p$-w-eu & $2.6 \pm 0.66$ & $2.2 \pm 0.85$ & $1.1 \pm 0.22$ & $2.9 \pm 0.14$ & $0.87 \pm 0.01$ & $0.08 \pm 0.01$ \\
\hline & Glu & $44.9 \pm 2.84$ & $23.3 \pm 4.24$ & $1.6 \pm 0.82$ & $12.8 \pm 0.09$ & $2.77 \pm 0.04$ & $0.12 \pm 0.05$ \\
\hline $4,8,10,17,21$ & $H S f-s-p h$ & $74.1 \pm 10.7$ & $84.6 \pm 10.1$ & $18.1 \pm 4.90$ & $57.4 \pm 16.8$ & $58.8 \pm 14.8$ & $13.2 \pm 0.35$ \\
\hline $5,11,14,19,20$ & $H S s-p h$ & $80.4 \pm 8.40$ & $85.8 \pm 7.37$ & $13.5 \pm 4.21$ & $62.4 \pm 9.92$ & $60.2 \pm 10.1$ & $2.78 \pm 0.22$ \\
\hline $6,13,15,16$ & $H S s-d$ & $77.6 \pm 11.3$ & $66.7 \pm 9.18$ & $59.0 \pm 8.14$ & $54.5 \pm 15.6$ & $57.8 \pm 14.6$ & $71.7 \pm 16.4$ \\
\hline $7,9,12,18$ & $H S f-s-d$ & $90.1 \pm 7.61$ & $74.8 \pm 7.53$ & $60.8 \pm 9.15$ & $65.5 \pm 10.7$ & $79.1 \pm 7.3$ & $67.9 \pm 9.7$ \\
\hline
\end{tabular}

Explanations under Table 1
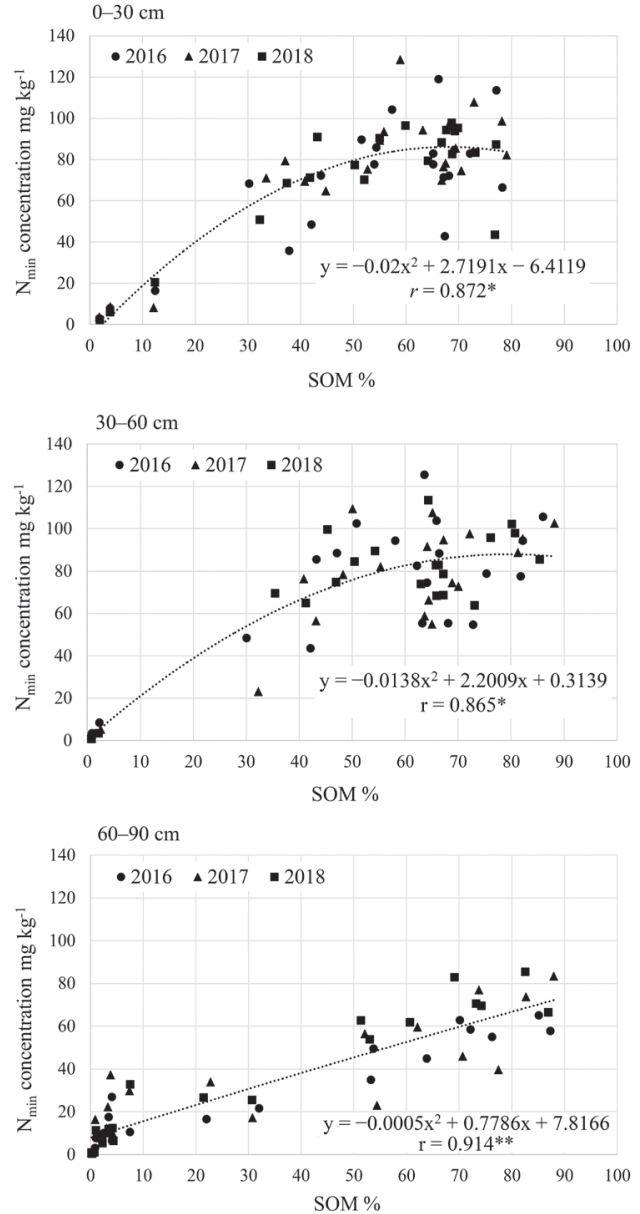

Figure 2. The dependence of mineral nitrogen $\left(\mathrm{N}_{\min }\right)$ content at the $0-30,30-60$ and $60-90 \mathrm{~cm}$ soil layers on the concentration of soil organic matter $(\mathrm{SOM})(\mathrm{n}=21)$ in 2016-2018
Table 3. The distribution of carbon-to-nitrogen ratio $(\mathrm{C}: \mathrm{N})$ in the studied soils at the $0-30,30-60$ and $60-90$ $\mathrm{cm}$ layers

\begin{tabular}{cccc}
\hline Soil code & \multicolumn{3}{c}{ Soil sampling depth } \\
\cline { 2 - 4 } according to & $0-30 \mathrm{~cm}$ & $30-60 \mathrm{~cm}$ & $60-90 \mathrm{~cm}$ \\
\cline { 2 - 4 } FAO & \multicolumn{3}{c}{ C:N in soil $\pm \mathrm{SD}$} \\
\hline ARg-p-w-eu & $11.3 \pm 1.15$ & $8.3 \pm 0.82$ & - \\
Glu & $12.8 \pm 0.92$ & $19.5 \pm 1.15$ & - \\
$H S s-p h$ & $19.6 \pm 3.43$ & $27.2 \pm 4.17$ & $4.2 \pm 0.84$ \\
$H S f-s-p h$ & $16.1 \pm 3.91$ & $29.3 \pm 2.41$ & $5.5 \pm 0.59$ \\
$H S f-s-d$ & $18.7 \pm 2.28$ & $28.1 \pm 1.43$ & $34.1 \pm 4.23$ \\
$H S s-d$ & $20.3 \pm 5.14$ & $25.4 \pm 2.16$ & $26.3 \pm 2.81$ \\
\hline
\end{tabular}

ARg-p-w-eu - Eutri-Epihypogleyic Arenosol, Glu-ha - HapliUmbric Geysol, HSs-d - Bathiterric Histosol (low moor deep peat soils $\geq 100 \mathrm{~cm}$ ), HSs-ph - Pachiterric Histosol (low moor shallow peat soils $40-100 \mathrm{~cm}$ ), HSf-s-d - Bathifibric-Fibric Histosol (high moor deep peat soils $\geq 100 \mathrm{~cm}$ ), HSf-s-ph Pachiterri-Fibric Histosol (high moor shallow peat soils 50$100 \mathrm{~cm}$ ); SD - standard deviation of the mean

equation $\mathrm{y}=1.987 \mathrm{x}-6.77$. At the $30-60 \mathrm{~cm}$ layer, a strong correlation $\left(r=0.74^{*}\right)$ was obtained, and the equation $\mathrm{y}=38 \mathrm{x}-18.9$. In the studied Histosols, at the 60-90 cm layers there was either peat or mineral soil layer; therefore, the $\mathrm{C}: \mathrm{N}$ fluctuated in a wide range $4-34$. There was no correlation $(r=0.29)$ at this layer.

It should be noted that the content of $\mathrm{N}_{\min }$ in Histosols was significantly higher compared to mineral soils. This is confirmed by the data of other researchers. For example, according to the monitoring data of Latvian researchers, the content of $\mathrm{N}_{\text {in }}$ at the $0-60 \mathrm{~cm}$ layer in mineral soils varied between 25 and $60 \mathrm{~kg} \mathrm{ha}^{-1}$ (Čermák, Kubík, 2009; Loide et al., 2009); according to Polish researchers: at the $0-30 \mathrm{~cm}$ layer $-22.5-112 \mathrm{~kg} \mathrm{ha}^{-1}$ in spring and 23.5-146 kg ha ${ }^{-1}$ in autumn (Fotyma et al., 2009). The 10-year monitoring data in Lithuania showed that $\mathrm{N}_{\min }$ content varied from 3.2 to $9.5 \mathrm{mg} \mathrm{ha}^{-1}$ at the 0-60 $\mathrm{cm}$ layer in mineral soils (Staugaitis et al., 2007). 
Results of other studies of natural climate zones are compared (Loch et al., 2009; Wiesler, Armbruster, 2009). High $\mathrm{N}_{\min }$ content in Histosols changes the approach to assessing $\mathrm{N}_{\text {min }}$ content in these soils, both for individual plants and for samples taken from different depths. Therefore, the existing methodological framework (Rutkowska, Fotyma, 2011) according to which $\mathrm{N}_{\text {mi }}$ sampling from the $0-60$ or $0-90 \mathrm{~cm}$ layers is conducted and the data obtained evaluated is not appropriate for Histosols. Considering that the content of $\mathrm{N}_{\text {in }}$ was heavily dependent on the content of SOM and $\mathrm{C}: \mathrm{N}$ in soil, the content of SOM and C:N should be taken into consideration while assessing $\mathrm{N}_{\min }$ content in Histosols and even Gleysols.

\section{Conclusions}

1. The contents of mineral nitrogen $\left(\mathrm{N}_{\text {min }}\right)$ in Histosols were significantly higher compared to those in mineral soils, and widely ranged at different depths as follows: 37.5 to $128.2 \mathrm{mg} \mathrm{kg}^{-1}$ at $0-30 \mathrm{~cm}, 22.9$ to $143.4 \mathrm{mg} \mathrm{kg}^{-1}$ at $30-60 \mathrm{~cm}$ and 5.2 to $85.3 \mathrm{mg} \mathrm{kg}^{-1}$ at $60-90 \mathrm{~cm}$.

2. $\mathrm{N}_{\text {min }}$ content at the $0-30$ and $30-60 \mathrm{~cm}$ layers was lower in Bathiterric Histosol and Bathifibric-Fibric Histosol: it was $77.6 \pm 11.3$ and $74.0 \pm 7.61 \mathrm{mg} \mathrm{kg}^{-1}$ at the $0-30 \mathrm{~cm}$ and $66.7 \pm 9.18$ and $74.8 \pm 7.53 \mathrm{mg} \mathrm{kg}^{-1}$ at the 30-60 cm layers, respectively. Meanwhile, $\mathrm{N}_{\min }$ content in Pachiterric Histosol and Pachiterri-Fibric Histosol was higher: $80.4 \pm 8.40$ and $90.1 \pm 10.7 \mathrm{mg} \mathrm{kg}^{-1}$ at the $0-30 \mathrm{~cm}$ and $85.8 \pm 7.37$ and $84.6 \pm 10.1 \mathrm{mg} \mathrm{kg}^{-1}$ at the 30-60 cm layers, respectively.

3. The content of $\mathrm{N}$ in Histosols depended on the peat layer thickness. At the $60-90 \mathrm{~cm}$ layer in Pachiterric Histosol and Pachiterri-Fibric Histosol, mineral soil was already present in many of the profiles, and soil organic matter (SOM) was lower; therefore, $\mathrm{N}_{\min }$ content was lower as well $-13.5 \pm 4.21$ and 18.1 $\pm 4.90 \mathrm{mg} \mathrm{kg}^{-1}$, respectively, whereas in Bathiterric Histosol and Bathifibric-Fibric Histosol it was $59.0 \pm$ 8.14 and $60.8 \pm 9.15 \mathrm{mg} \mathrm{kg}^{-1}$, respectively.

4. The content of $\mathrm{N}_{\min }\left(\mathrm{y}, \mathrm{mg} \mathrm{kg}^{-1}\right)$ in Histosols was strongly dependent on the concentration of SOM in the soil (x, \%). At the $0-30 \mathrm{~cm}$ layer, this dependence is expressed by the equations $\mathrm{y}=-0.02 \mathrm{x}^{2}+2.72 \mathrm{x}-6.41$ $\left(r=0.87^{*}\right)$, at 30-60 cm layer $-\mathrm{y}=-0.01 \mathrm{x}^{2}+2.2 \mathrm{x}+$ $0.31\left(r=0.87^{*}\right)$, and at $60-90 \mathrm{~cm}$ layer $-\mathrm{y}=0.78 \mathrm{x}+$ $7.82(r=0.92 * *)$.

5. The ratio of carbon-to-nitrogen $(\mathrm{C}: \mathrm{N})$ most influenced $\mathrm{N}_{\text {min }}$ content at the $0-30 \mathrm{~cm}$ layer, with a very strong correlation between the $\mathrm{C}: \mathrm{N}$ and $\mathrm{N}_{\text {min }}$ content. At the $30-60 \mathrm{~cm}$ layer, the correlation between the $\mathrm{C}: \mathrm{N}$ and $\mathrm{N}_{\min }$ content was weak, resulting in a significant influence of SOM concentration on $\mathrm{N}$ content. At the $60-90 \mathrm{~cm}$ layer, in the shallow peat soils mineral horizon dominated, resulting in a high variation of the $\mathrm{C}: \mathrm{N}$ from 4 to 34 and there was no correlation between the $\mathrm{C}: \mathrm{N}$ and $\mathrm{N}_{\min }$ content.

Received 18072019

Accepted 04112019

\section{References}

1. Arbačauskas J., Masevičienė A., Žičkienė L., Staugaitis G. 2018. Mineral nitrogen in soils of Lithuania's agricultural land: comparison of oven-dried and field-moist samples Zemdirbyste-Agriculture, 105 (2): 99-104. https://doi.org/10.13080/z-a.2018.105.013

2. Arbačiauskas J., Staugaitis G., Vaišvila Z., Mažvila J., Adomaitis T., Sumskis D. 2014. The interdependence of mineral nitrogen content in different soil layers of Lithuanian agricultural lands. Zemdirbyste-Agriculture, $101(2): 133-138$.

https://doi.org/10.13080/z-a.2014.101.017
3. Aurangojeb M., Klemedtsson L., Rütting T., He H., Weslien P., Banzhaf S., Kasimir A. 2017. Nitrous oxide emissions from Norway spruce forests on drained organic and mineral soil. Canadian Journal of Forest Research, 47 (11): 1482-1487.

https://doi.org/10.1139/cjfr-2016-0541

4. Burri S., Niklaus P., Grassow K., Buchmann N., Kahmen A. 2018. Effects of plant productivity and species richness on the drought response of soil respiration in temperate grasslands. PLoS ONE, 13 (12): 1-18. https://doi.org/10.1371/journal.pone.0209031

5. Castillo M. S., Writ A. L. 2008. Soil phosphorus pools for Histosols under sugarcane and pasture in the Everglades, USA. Geoderma, 145 (1-2): 130-135.

https://doi.org/10.1016/j.geoderma.2008.03.006

6. Cermák P., Kubík L. 2009. Monitoring of nitrogen content in the soil and water. Fertilizers and Fertilization, 37: 32-42.

7. Chambers F. M., Beilman D. W., Yu Z. 2010. Methods for determining peat humification and for quantifying peat bulk density, organic matter and carbon content for palaeostudies of climate and peatland carbon dynamics. Mires and Peat, 7: 12-18.

8. Dawson J., Huggins D., Jones S. 2008. Characterizing nitrogen use efficiency in natural and agricultural ecosystems to improve the performance of cereal crops in low-input and organic agricultural systems. Field Crops Research, 107: 89-101. https://doi.org/10.1016/j.fcr.2008.01.001

9. Deng J., Sun P., Zhao F., Han X., Yang G., Feng Y. 2016. Soil C, N, P and its stratification ratio affected by artificial vegetation in subsoil, Loess Plateau China. PLoS ONE, 11(3): e0151446. https://doi.org/10.1371/journal.pone.0151446

10. Fotyma E., Fotyma M., Pietruch C. 2009. The content of soil mineral nitrogen in Poland. Fertilizers and Fertilization, 2 (23): 41-48.

11. Friesen P. C., Cattani D. J. 2017. Nitrogen use efficiency and productivity of first year switchgrass and big bluestem from low to high soil nitrogen. Biomass and Bioenergy, 107: $317-325$. https://doi.org/10.1016/j.biombioe.2017.10.016

12. Grandy A. S., Sinsabaugh R. L., Neff J. C., Stursova M., Zak D. R. 2008. Nitrogen deposition effects on soil organic matter chemistry are linked to variation in enzymes, ecosystems and size fractions. Biogeochemistry, 91: 37-49. https://doi.org/10.1007/s10533-008-9257-9

13. Johnston C. A., Bridgham S. D., Schubauer-Berigan J. P. 2001. Nutrient dynamics in relation to geomorphology of riverine Wetlands. Soil Science Society of America Journal, 65 (2): 557-562. https://doi.org/10.2136/sssaj2001.652557x

14. Loch J., Emese B. S., Pirko B. 2009. Nitrogen fertilizer advisory system and monitoring in Hungary. Fertilizers and Fertilization, 37: 59-72.

15. Loide V., Köster T., Penu P., Rebane J. 2009. The implementation recommendations and restrictions for using nitrogen fertilizers in Estonia. Fertilisers and Fertilization, 37: 43-49.

16. Nikitin B. A. 1999. Methods for soil humus determination. AgroChemistry, 3 (2): 156-158.

17. Norberg L., Berglund Ö., Berglund K. 2016. Seasonal CO emission under different cropping systems on Histosols in southern Sweden. Geoderma Regional, 7 (3): 338-345. https://doi.org/10.1016/j.geodrs.2016.06.005

18. Parvage M. M., Ulén B., Kirchmann H. 2015. Nutrient leaching from manure-amended topsoils (Cambisols and Histosols) in Sweden. Geoderma Regional, 5: 209-214. https://doi.org/10.1016/j.geodrs.2015.08.003

19. Petersen R. G. 1994. Combined analysis of several experiments. Petersen R. G. (ed.) Agricultural field experiments: design and analysis. CRC Press, p. 205-206.

20. Rezanezhad F. Price J S. Quinton W. L., Lennartz B. Milojevic T., Van Cappellen P. 2016. Structure of peat soils and implications for water storage, flow and solute transport: a review update for geochemists. Chemical Geology, 429: 75-84. https://doi.org/10.1016/j.chemgeo.2016.03.010

21. Robertson G., Vitousek P. 2009. Nitrogen in agriculture: balancing the cost of an essential resource. Annual Review of Environment and Resources, 34: 97-125. https://doi.org/10.1146/annurev.environ.032108.105046

22. Ruehlmann J., Körschens M. 2009. Calculating the effect of soil organic matter concentration on soil bulk density. Soil Science Society of America Journal, 73: 876-882. https://doi.org/10.2136/sssaj2007.0149 
23. Rutkowska A., Fotyma M. 2011. Mineral nitrogen as a universal soil test to predict plant $\mathrm{N}$ requirements and ground water pollution - case study for Poland. Soil Science, 22: 333-350. https://doi.org/10.5772/29397

24. Shcherbak I., Millar N., Robertson G. P. 2014. Global metaanalysis of the nonlinear response of soil nitrous oxide $\left(\mathrm{N}_{2} \mathrm{O}\right)$ emissions to fertilizer nitrogen. Proceedings of the National Academy of Sciences, 111 (25): 9199-9204. https://doi.org/10.1073/pnas.1322434111

25. Sommer S., Schjoerring J., Denmead O. 2004. Ammonia emission from mineral fertilizers and fertilized crops. Advances in Agronomy, 82: 557-622. https://doi.org/10.1016/S0065-2113(03)82008-4

26. Staugaitis G., Vaisvila Z., Mazvila J., Arbaciauskas J., Adomaitis T., Fullen M. A. 2007. Role of soil mineral nitrogen for agricultural crops: nitrogen nutrition diagnostics in Lithuania. Archives of Agronomy and Soil Science, 53 (3): 263-271. https://doi.org/10.1080/03650340701223338

27. Staugaitis G., Žičkienė L., Mažvila J., Arbačiauskas J. Šmskis D., Masevičienè A., Staugaitienè R. 2014. The regularities of mineral nitrogen distribution in Lithuania's soils in spring. Zemdirbyste-Agriculture, 102 (4): 371-380. https://doi.org/10.13080/z-a.2015.102.047

28. Steffens M., Kohlpaintner M., Buddenbaum H. 2014. Fine spatial resolution mapping of soil organic matter quality in a Histosol profile. European Journal of Soil Science, 65: 827-839. https://doi.org/10.1111/ejss.12182

29. Tian L., Dell E., Shi W. 2010. Chemical composition of dissolved organic matter in agroecosystems: correlations with soil enzyme activity and carbon and nitrogen mineralization. Applied Soil Ecology, 46 (3): 426-435. https://doi.org/10.1016/j.apsoil.2010.09.007

30. Tripolskaja L., Razukas A., Sidlauskas G., Verbyliene I. 2017. Effect of fertilizers with different chemicalcomposition on crop yield, nitrogen uptake and leaching in a loam Luvisol. Zemdirbyste-Agriculture, 104 (3): 203-208. https://doi.org/10.13080/z-a.2017.104.026

31. Truong T. H. H., Marschner P. 2018. Respiration, available $\mathrm{N}$ and microbial biomass $\mathrm{N}$ in soil amended with mixes of organic materials differing in $\mathrm{C} / \mathrm{N}$ ratio and decomposition stage. Geoderma, 319: 167-174.

https://doi.org/10.1016/j.geoderma.2018.01.012
32. Vasilevich R., Lodygin E., Beznosikov V., Abakumov E. 2018. Molecular composition of raw peat and humic substances from permafrost peat soils of European Northeast Russia as climate change markers. Science of the Total Environment, 615: 1229-1238. https://doi.org/10.1016/j.scitotenv.2017.10.053

33. Volungevičius J., Amalevičiūtė K., Liaudanskienè I., Slepetiené A. 2015. Chemical properties of Pachiterric Histosoil as influenced by different land use. ZemdirbysteAgriculture, 102 (2): 123-132. https://doi.org/10.13080/z-a.2015.102.016

34. Wang Q., Wang D., Wen X., Yu G., He N., Wang R. 2015. Differences in SOM decomposition and temperature sensitivity among soil aggregate size classes in a temperate grasslands. PLoS ONE, 10: e0117033. https://doi.org/10.1371/journal.pone.0117033

35. Wasiu A. L., Onyegbula C. N., Kabiru A. S. 2018. Assessment of soil characteristics under four cropping and land management systems in south west Nigeria. African Journal of Agricultural Research, 13 (27): 1400-1406. https://doi.org/10.5897/AJAR2017.12227

36. Wei X., Wang X., Ma T., Huang L., Pu Q., Hao M., Zhang X. 2017. Distribution and mineralization of organic carbon and nitrogen in forest soils of the southern Tibetan Plateau. Catena, 156: 298-304. https://doi.org/10.1016/j.catena.2017.04.016

37. Wiesler F., Armbruster M. 2009. The application of the $\mathrm{N}$ soil test as an element of integrated nitrogen management strategies in agriculture. Fertilizers and Fertilization, 37: $50-58$.

38. WRB. 2014. World reference base for soil resources. World Soil Resources Reports No. 106. FAO, 192 p.

39. Zang X., van Heemst J. D. H., Dria K. J., Hatcher P. G. 2000. Encapsulation of protein in humic acid from a Histosol as an explanation for the occurrence of organic nitrogen in soil and sediment. Organic Geochemistry, 31 (7-8): 679-695. https://doi.org/10.1016/S0146-6380(00)00040-1

40. Zhang X., Wang Q., Xu J., Frank S., Gilliam F. S., Tremblay N., Li C. 2015. In situ nitrogen mineralization, nitrification, and ammonia volatilization in maize field fertilized with urea in Huanghuaihai Region of Northern China. PLoS ONE, 10 (1): 1-15. https://doi.org/10.1371/journal.pone.0115649

ISSN 1392-3196 / e-ISSN 2335-8947

Zemdirbyste-Agriculture, vol. 107, No. 1 (2020), p. 11-16

DOI $10.13080 /$ z-a.2020.107.002

\title{
Mineralinio azoto kiekis durpžemiuose ir jo sąsajos su dirvožemio organine medžiaga
}

\author{
G. Staugaitis, A. Šarka
}

Lietuvos agrarinių ir miškų mokslų centro Agrocheminių tyrimų laboratorija

\section{Santrauka}

Tyrimo tikslas - ištirti mineralinio azoto $\left(\mathrm{N}_{\min }\right)$ koncentracijas durpžemių (Histosols) 0-30, 30-60 bei 60-90 cm sluoksniuose ir jo sąsajas su dirvožemio organine medžiaga. Tyrimas atliktas 2016-2018 m. Lietuvoje natūraliose pievose arba jau daug metų naudojamose kultūrinèse pievose. Jose buvo ịrengta 21 aikštelè, kuriose kiekvienais metais mineralinis azotas tyrimui imtas lapkričio mėnesị. Tyrimo metu nustatyta, kad $\mathrm{N}_{\text {min }}$ koncentracija durpžemiuose, lyginant su mineraliniais dirvožemiais, buvo reikšmingai didesné, o įvairiame gylyje orasausiame dirvožemyje svyravo plačiu intervalu: 0-30 cm sluoksnyje - nuo $37,5 \mathrm{iki} 128,2 \mathrm{mg} \mathrm{kg}{ }^{-1}, 30-60 \mathrm{~cm}$ sluoksnyje - nuo 22,9 iki $143,4 \mathrm{mg} \mathrm{kg}^{-1}, 60-90 \mathrm{~cm}$ - nuo 5,2 iki 85,3 $\mathrm{mg} \mathrm{kg}^{-1}$. Mineralinio azoto koncentracija 0-30 ir 30-60 cm sluoksniuose buvo mažesnè giliuose žemapelkès durpžemiuose ir giliuose tarpinès pelkès durpžemiuose nei sekliuose aukštapelkès durpžemiuose ir sekliuose tarpinės pelkès durpžemiuose. Be to, $\mathrm{N}_{\min }$ koncentracija durpžemiuose priklausė nuo durpių sluoksnio gylio. Sekliuose aukštapelkès durpžemiuose ir sekliuose tarpinės pelkès durpžemiuose daugelyje profilių 60-90 cm sluoksnyje mineralinis dirvožemis turèjo mažesnị kiekị organinių medžiagų, todèl jame nustatyta mažesné $\mathrm{N}_{\min }$ koncentracija. Durpžemiuose $\mathrm{N}_{\min }$ koncentracija $\left(\mathrm{y}, \mathrm{mg} \mathrm{kg}^{-1}\right)$ priklausè nuo organinių medžiagų koncentracijos dirvožemyje $(\mathrm{x}, \%)$. Sis priklausomumas $0-30 \mathrm{~cm}$ sluoksnyje pavaizduotas lygtimis $\mathrm{y}=-0,02 \mathrm{x}^{2}+2,72 \mathrm{x}-6,41$ $\left(r=0,87^{*}\right), 30-60 \mathrm{~cm}$ sluoksnyje $-\mathrm{y}=-0,01 \mathrm{x}^{2}+2,2 \mathrm{x}+0,31\left(r=0,87^{*}\right), 60-90 \mathrm{~cm}$ sluoksnyje $-\mathrm{y}=0,78 \mathrm{x}+$ $7,82\left(r=0,92^{* *}\right)$. Durpžemių $0-30 \mathrm{~cm}$ sluoksnyje anglies ir azoto santykis $(\mathrm{C}: \mathrm{N})$ buvo vidutiniškai 18 ; nustatytas labai stiprus koreliacinis ryšys tarp C:N ir $\mathrm{N}_{\text {min }}$ koncentracijos. 30-60 cm sluoksnyje C:N sudare vidutiniškai 27, nustatytas silpnas koreliacinis ryšys, todèl didesnę ịtaką $\mathrm{N}_{\min }$ koncentracijai turèjo didelè SOM koncentracija. 60 $90 \mathrm{~cm}$ sluoksnyje sekliuose durpžemiuose vyravo mineralinis horizontas, todėl C:N svyravimas buvo didelis - nuo 4 iki 34, ir nenustatyta koreliacinio ryšio tarp C: $\mathrm{N}$ ir $\mathrm{N}_{\min }$ koncentracijos.

Reikšminiai žodžiai: dirvožemio organinė medžiaga, Histosols, mineralinis azotas. 